\title{
Reference values for IGF-I serum concentration in an adult population: use of the VARIETE cohort for two new immunoassays
}

\author{
Nadia Sabbah ${ }^{1,2, *}$, Peter Wolf ${ }^{1,3, *}$, Céline Piedvache ${ }^{4}$, Séverine Trabado ${ }^{5}$, Tristan Verdelet ${ }^{1}$, Catherine Cornu ${ }^{6}$, \\ Jean-Claude Souberbielle ${ }^{7}$ and Philippe Chanson ${ }^{11}$ on behalf of the VARIETE Investigators
}

\begin{abstract}
${ }^{1}$ Université Paris-Saclay, Inserm, Physiologie et Physiopathologie Endocriniennes, Assistance Publique-Hôpitaux de Paris, Hôpital de Bicêtre, Service d'Endocrinologie et des Maladies de la Reproduction, Centre de Référence des Maladies Rares de l'Hypophyse, Le Kremlin-Bicêtre, France ${ }^{2}$ Hôpital de Cayenne, Service d'Endocrinologie et des Maladies Métaboliques, Cayenne, Guyane Française

${ }^{3}$ Division of Endocrinology and Metabolism, Department of Internal Medicine III, Medical University of Vienna, Vienna, Austria

${ }^{4}$ Assistance Publique-Hôpitaux de Paris, Hôpital de Bicêtre, Unité de Recherche Clinique, Le Kremlin-Bicêtre, France

${ }^{5}$ Université Paris-Saclay, Inserm, Physiologie et Physiopathologie Endocriniennes, Assistance Publique-Hôpitaux de Paris, Hôpital de Bicêtre, Service de Génétique Moléculaire, Pharmacogénétique et Hormonologie, Le Kremlin-Bicêtre, France

${ }^{6}$ Centre d'Investigation Clinique, INSERM CIC1407/UMR5558, Hospices Civils de Lyon, Bron, France

${ }^{7}$ Assistance Publique-Hôpitaux de Paris, Hôpital Necker, Service d'Explorations Fonctionnelles, Paris, France
\end{abstract}

Correspondence should be addressed to P Chanson: philippe.chanson@bct.aphp.fr

*(N Sabbah and P Wolf contributed equally to this work)

\begin{abstract}
Objective: Measurement of IGF-I is important in the management of patients with growth hormone disorders. Here we aim to establish normative data for two new IGF-I assay kits based on a large random sample of the French general adult population.

Subjects and methods: We measured IGF-I in 911 healthy adults (18-90 years) with two immunoassays (ROCHE Elecsys ${ }^{\circledR}$ and IMMULITE-2000 calibrated against the new IS 02/2547). We compared the data with those of the six immunoassays (iSYS, LIAISON XL, IMMULITE-2000 calibrated against the first IS 87/518, IGF-I RIACT, Mediagnost ELISA, and Mediagnost RIA) that we reported previously. The pairwise concordance among the eight assays was assessed with Bland-Altman plots for both the IGF-1 raw data and the standard deviation scores (SDS), as well as with the percentage of observed agreement and the weighted Kappa coefficient for categorizing IGF-I SDS (ClinicalTrials.gov Identifier: NCT01831648).

Results: The normative data included the range of values (2.5-97.5 percentiles) given by the two new IGF-I assays according to age group and sex. A formula for the SDS calculation is provided. As for the previous six assays, the lower limits of the reference intervals of the two new assays were similar, but the upper limits varied markedly. The pairwise concordances were only moderate (kappa 0.57).

Conclusions: Data obtained for these two new IGF-I immunoassays confirm that despite being obtained in the same large healthy population, the reference intervals of the eight commercial IGF-1 assay kits showed noteworthy differences. The agreement among the various methods was moderate to good.
\end{abstract}

\section{Key Words}

- IGF-I

- Z-score

- SD score

- normative data

- reference range

- normal healthy population

- acromegaly

- growth hormone deficiency https://ec.bioscientifica.com

https://doi.org/10.1530/EC-21-0175 (c) 2021 The authors Published by Bioscientifica Ltd

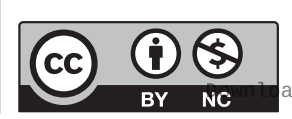

This work is licensed under a Creative Commons Attribution-NonCommercial 4.0 International License. ded from Bioscientifica.com at 04/26/2023 08:46:11AM
Endocrine Connections (2021) 10, 1027-1034 


\section{Introduction}

IGF-1 measurement is important for the diagnosis and management of patients with growth hormone (GH) deficiency or acromegaly as well as in their follow-up $(1,2)$. We previously established normative data for six IGF-I assays using the same large healthy population (3). We, as well as others, also showed that there were some discordances among the assays $(3,4)$, which could be explained by several reasons, such as the pre-analytical or analytical conditions, particularly the dissociation method applied to the interaction between the IGF-I and IGFbinding proteins. Another cause of the discordance could be the calibration against different IGF-I preparations, but this would normally not be the case, since, in 2011, the Growth Hormone Research Society and the International Society for IGF Research proposed standardizing the calibration standard (WHO NIBSC 02/254) for all IGF-1 assay kits (the new standard used being 02/2547) (5). In a cross-sectional study, we also measured IGF-I with the same six immunoassays in 102 patients with active or treated acromegaly or GH deficiency and observed marked variability both across each individual's IGF-I raw data and across the IGF-I SDS values (6). The agreement among the IGF-I assay methods was only moderate to good, leading to the conclusion that the use of the same IGF-I assay for a given patient throughout follow-up is highly recommended.

The aim of the present study was to establish normative data for two new commercial IGF-I assays in the same large random sample of healthy subjects from the French general population that we used in our previous study. This cohort (VARIETE cohort) represents all adult age groups (approximately 100 subjects per decade), as recommended by the Consensus Group on the Standardization and Evaluation of GH and IGF-I assays (5) after careful exclusion of subjects with medical conditions or medications that might affect their IGF-I concentration. The data were analyzed to obtain the range (2.5-97.5 percentiles) in mass units and the standard deviation scores, which were both used to compare the two new assays and the six previously reported assays.

\section{Subjects and methods}

\section{IGF-1 assay characteristics}

Two new immunoassays, the ROCHE Elecsys and IMMULITE 2000, both calibrated against the new generation SI 02-254 (7), were used to measure the IGF-I concentrations. Details concerning the six IGF-I immunoassays (iSYS, LIAISON XL, IMMULITE 2000 calibrated against the old standard, IGF1 RIACT, Mediagnost ELISA, and Mediagnost RIA) are provided in our previous publication $(3,6)$. The main characteristics of the two new assays and the mathematical models used to determine the normative data, where relevant as provided by the manufacturer, are shown in Table 1.

\section{Healthy subjects}

The subjects were part of a large cohort of healthy French adults (VARIETE). The VARIETE cohort was an open, prospective, national, multicenter, nonrandomized study of healthy volunteers designed to establish normative data for IGF-I and other hormones in the French general adult population, representing all age groups (approximately 100 subjects per decade from 18 to 90 years), as reported previously (3) (ClinicalTrials.gov Identifier: NCT01831648). In brief, a total of 972 healthy subjects with BMI values between 19 and $28 \mathrm{~kg} / \mathrm{m}^{2}$ were recruited, and serum samples were obtained.

All healthy subjects gave their written informed consent to participate in the study, which was approved by the Paris-Sud Ethics Committee before beginning the study.

\section{Statistical methods}

The distribution of IGF-I values obtained with each assay was skewed and was thus first normalized by means of sex- and age-specific Box-Cox power transformation. Men and women had significantly different IGF-I levels; thus, to calculate the SDSs, curves were constructed separately using the LMS method, as described in detail previously $(3,6)$. Pairwise concordance between assays was assessed with scatter plots and Bland-Altman plots for both the IGF-I raw values and the SDS values, as well as with the percentage of observed agreement (total number of agreements divided by the total number of patients tested with both assays) and the linearly weighted Kappa coefficient for categorized IGF-I SDS $(8,9)$. An overall kappa coefficient (8) and Friedman's test were computed for global comparison of all assays at the same time. Landis and Koch's table was followed for interpretation of the kappa values (10). SAS software was used for all statistical analyses (Statistical Analysis System, version 9.4, SAS Institute).

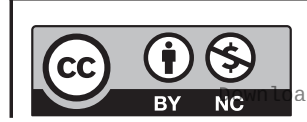




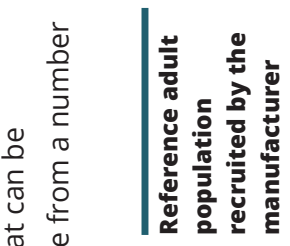
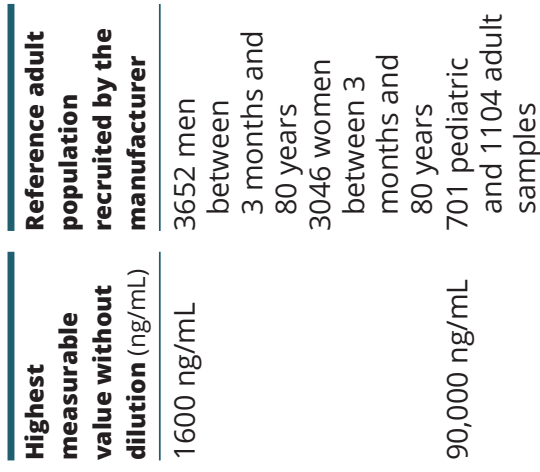

$\overrightarrow{1}$
है
ᄃ
8
8
वे
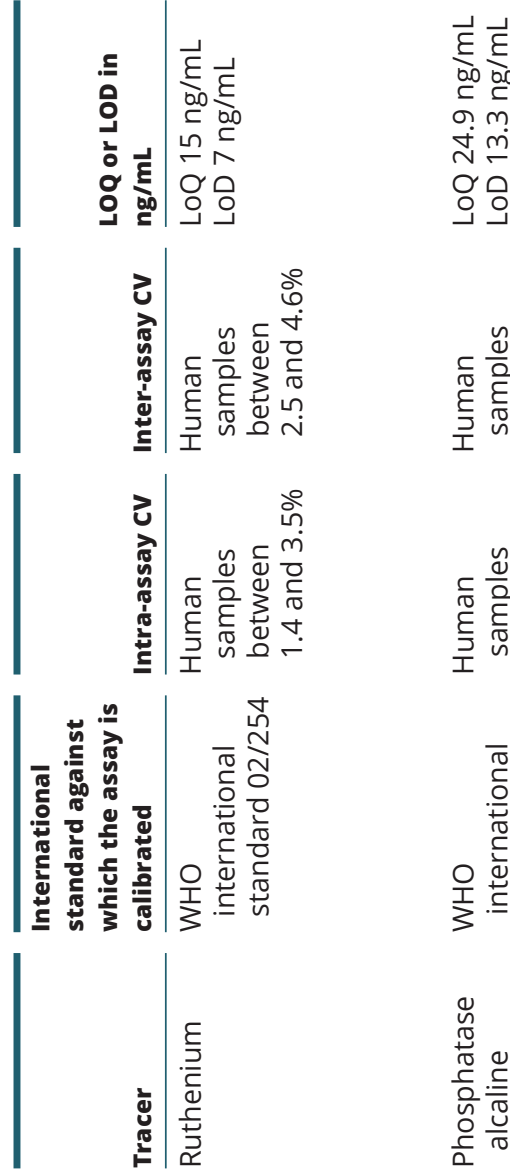

छ

\section{Results}

\section{Description of the population}

As previously reported (3), the study population consisted of 911 subjects (470 males), comprising 101, 118, 99, $98,103,102,108,97$, and 85 subjects in the 18-20, 21-23, 24-26, 27-29, 30-39, 40-49, 50-59, 60-69, and 70-89 year age groups, respectively. Their mean BMI was $23.0 \pm 2.4 \mathrm{~kg} / \mathrm{m}^{2}$.

\section{IGF-I reference intervals obtained with the new IMMULITE 2000 and ROCHE Elecsys ${ }^{\circledR}$ assays}

The IGF-I reference intervals (2.5-97.5th percentiles) obtained with the two new immunoassays (Immulite 2000 and ROCHE Elecsys ${ }^{\circ}$ ) are shown in Table 2 according to age and sex, along with the intervals of the six other immunoassays tested in the same healthy population. Individual points and fitted percentiles (2.5, 50, and 97.5\%) for men and women for both IGF-I assays are depicted in Supplementary Fig. 1 (see section on supplementary materials given at the end of this article).

A calculator available online (http://ticemed_sa.upmc. fr/sd_score/) or by using the apps (IGF-I SD_score) downloadable for Android from Google Play and iOS from Apple Store (free of charge) allows us to obtain individual IGF-I SDS after entering the name of the assay, the individual IGF-I value obtained with the assay, and the sex and age of the individual.

The reference intervals for men and women for the two new assays, together with those of the six assays previously reported, are plotted on the same graph in Fig. 1. Although the lower limits of the reference intervals (2.5th percentiles) were quite similar, the upper limits (97.5th percentiles) varied markedly from one assay to another.

\section{Comparison of the IGF-I levels given by the eight IGF-I immunoassays}

The results obtained with each IGF-I assay were compared with those obtained with each of the other seven assays. Scatter plots and Bland-Altman plots based on the raw values and SDS for each pair of assays are shown in Supplementary Fig. 1. Figure 2 illustrates an example of good concordance (iSYS vs ROCHE Elecsys ${ }^{\circ}$ ), as shown by scatter plots and Bland-Altman plots of the raw values and SDS values (A-D), and an example of poor concordance (iSYS vs the new IMMULITE 2000) (E-H).

The concordance analysis among the eight assay kits assessed by the weighted kappa is given in Table 3 . 
Table 2 Normative reference intervals (95\% CI) of IGF-1 measured by eight assay methods according to age range and sex in a cohort of 899 healthy subjects.

\begin{tabular}{|c|c|c|c|c|c|c|c|c|c|}
\hline Age range & $n$ & $\begin{array}{c}\text { iSYS IGF-1 } \\
(\mathrm{ng} / \mathrm{mL}) \mathbf{9 5 \%}\end{array}$ & $\begin{array}{l}\text { LIAISON XL } \\
\text { IGF-1 } \\
(\mathrm{ng} / \mathrm{mL}) 95 \%\end{array}$ & $\begin{array}{c}\text { IMMULITE } \\
2000 \text { IGF-1 } \\
(\mathrm{ng} / \mathrm{mL}) \mathbf{9 5} \%\end{array}$ & $\begin{array}{c}\text { IGF-I-RIACT } \\
\text { IGF-1 }(\mathrm{ng} / \mathrm{mL}) \\
95 \%\end{array}$ & $\begin{array}{c}\text { Mediagnost } \\
\text { ELISA IGF-1 } \\
(\mathrm{ng} / \mathrm{mL}) 95 \%\end{array}$ & $\begin{array}{c}\text { Mediagnost RIA } \\
\text { IGF-1 (ng/mL) } \\
95 \%\end{array}$ & $\begin{array}{c}\text { ROCHE } \\
\text { Elecsys }^{\circledR} \\
\text { IGF-1 } \\
\text { (ng/mL) 95\% }\end{array}$ & $\begin{array}{c}\text { IMMULITE } \\
\text { new } \\
\text { standard } \\
\text { IGF-1 }(\mathrm{ng} / \mathrm{mL}) \\
95 \%\end{array}$ \\
\hline \multicolumn{10}{|c|}{ Males (years) } \\
\hline $18-20$ & 56 & $168-391$ & $186-453$ & $195-537$ & $197-486$ & $177-400$ & $168-430$ & $173-395$ & $117-295$ \\
\hline $21-23$ & 61 & $147-346$ & $168-411$ & $171-477$ & $173-430$ & $159-388$ & $150-337$ & $152-350$ & $105-266$ \\
\hline $24-26$ & 53 & $132-313$ & $153-377$ & $152-430$ & $155-389$ & $144-355$ & $135-308$ & $136-317$ & $96-243$ \\
\hline $27-29$ & 49 & $122-292$ & $142-351$ & $138-396$ & $143-363$ & $133-331$ & $126-289$ & $125-294$ & $89-227$ \\
\hline $30-39$ & 56 & $108-265$ & $124-310$ & $118-348$ & $127-329$ & $115-295$ & $112-265$ & $110-263$ & $80-206$ \\
\hline $40-49$ & 51 & $91-233$ & $106-271$ & $98-301$ & $107-286$ & $98-261$ & $97-237$ & $92-229$ & $70-184$ \\
\hline $50-59$ & 54 & $81-214$ & $97-252$ & $85-273$ & $94-262$ & $88-245$ & $86-218$ & $82-210$ & $61-164$ \\
\hline $60-69$ & 49 & $75-208$ & $92-245$ & $77-260$ & $87-250$ & $80-237$ & $82-214$ & $76-202$ & $56-154$ \\
\hline $70-89$ & 34 & $64-192$ & $80-220$ & $66-242$ & $75-231$ & $71-233$ & $72-200$ & $65-182$ & $52-145$ \\
\hline \multicolumn{10}{|c|}{ Females (years) } \\
\hline $18-20$ & 41 & $155-421$ & $191-483$ & $180-586$ & $169-517$ & $169-487$ & $161-412$ & $162-419$ & $102-324$ \\
\hline $21-23$ & 54 & $144-383$ & $176-448$ & $166-541$ & $159-476$ & $156-446$ & 149-379 & 149-384 & 101-304 \\
\hline $24-26$ & 45 & $134-353$ & $163-418$ & $153-501$ & $150-440$ & $144-412$ & $139-353$ & $138-354$ & $98-286$ \\
\hline $27-29$ & 48 & $126-330$ & $152-391$ & $142-467$ & $142-410$ & $134-385$ & $131-332$ & $128-329$ & $95-272$ \\
\hline $30-39$ & 47 & $113-294$ & $131-345$ & $121-403$ & $126-356$ & $118-341$ & $118-298$ & $112-286$ & $86-243$ \\
\hline $40-49$ & 50 & $97-253$ & $109-296$ & $98-331$ & $107-297$ & $100-296$ & $103-258$ & $94-242$ & $72-203$ \\
\hline $50-59$ & 54 & $80-209$ & $93-253$ & $80-271$ & $90-247$ & $82-248$ & $97-220$ & $77-203$ & $59-165$ \\
\hline $60-69$ & 47 & $64-170$ & $84-222$ & $68-227$ & $76-209$ & $68-208$ & $75-190$ & $66-174$ & $50-140$ \\
\hline $70-89$ & 50 & $56-154$ & $81-204$ & $60-188$ & $67-189$ & $60-187$ & $68-175$ & 59-159 & $50-134$ \\
\hline
\end{tabular}

The average concordance among the assays was only moderate, and the overall weighted kappa was 0.57.

\section{Discussion}

Here, we report sex-specific reference intervals for IGF-1 concentrations for two newly developed immunoassays, that is, the ROCHE Elecsys and the new IMMULITE 2000 calibrated against the new SI 02/2547 in a large representative sample of a healthy French population aged between 18 and 90 years. By strictly adhering to the latest consensus statement on the requirements for $\mathrm{GH}$ and IGF-1 assays of the Growth Hormone Research Society, the IGF Society, and the International Federation for Clinical Chemistry and Laboratory Medicine (5), our data add important knowledge to the interpretation of these new IGF-1 immunoassays.

The accurate and reliable detection of IGF-1 concentrations is indispensable for the diagnosis of GH-related disorders, as well as for the therapeutic management of individual patients $(1,2)$. However, there is a large variability in the reference ranges of commercially available IGF-1 assays, especially in the upper limits of the reference range, which is reflected by only moderate average concordance, which could be found in our study by comparing all eight immunoassays with each other. These variations in assay agreement were independent of the use of mass units or SD scores. This discordance might have important implications for clinical practice. This does not mean that an assay is better than another, which cannot be indicated by this study, this only means that the use of different IGF-1 assays for a single patient might affect treatment decisions and dose adjustments in children and adults, especially when IGF-1 levels are borderline $(6,11)$.

Establishing reference intervals for IGF-1 is complex. Indeed, the reference intervals vary according to age, especially during growth and adolescence, where differences are marked according to the pubertal stage, with an elevation during the child's growth (12) and conversely a decrease in adulthood (13). They also vary according to sex (14) and ethnicity $(15,16)$. Insulin resistance (17) and diabetes (18) regardless of obesity (19) also modify IGF-1 levels, even in acromegalic patients (20), as do nutritional disorders (21), renal failure, and hepatic insufficiency (22). Moreover, drugs such as estrogens can also alter IGF-1 levels (23). Thus, the use of a representative cohort of healthy subjects with stringently defined inclusion and exclusion criteria is necessary to avoid interference by any underlying comorbidities.

The strength of our study is that we compared all eight available immunoassays within the same large population

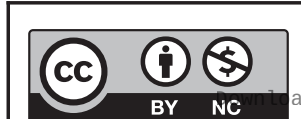


Females
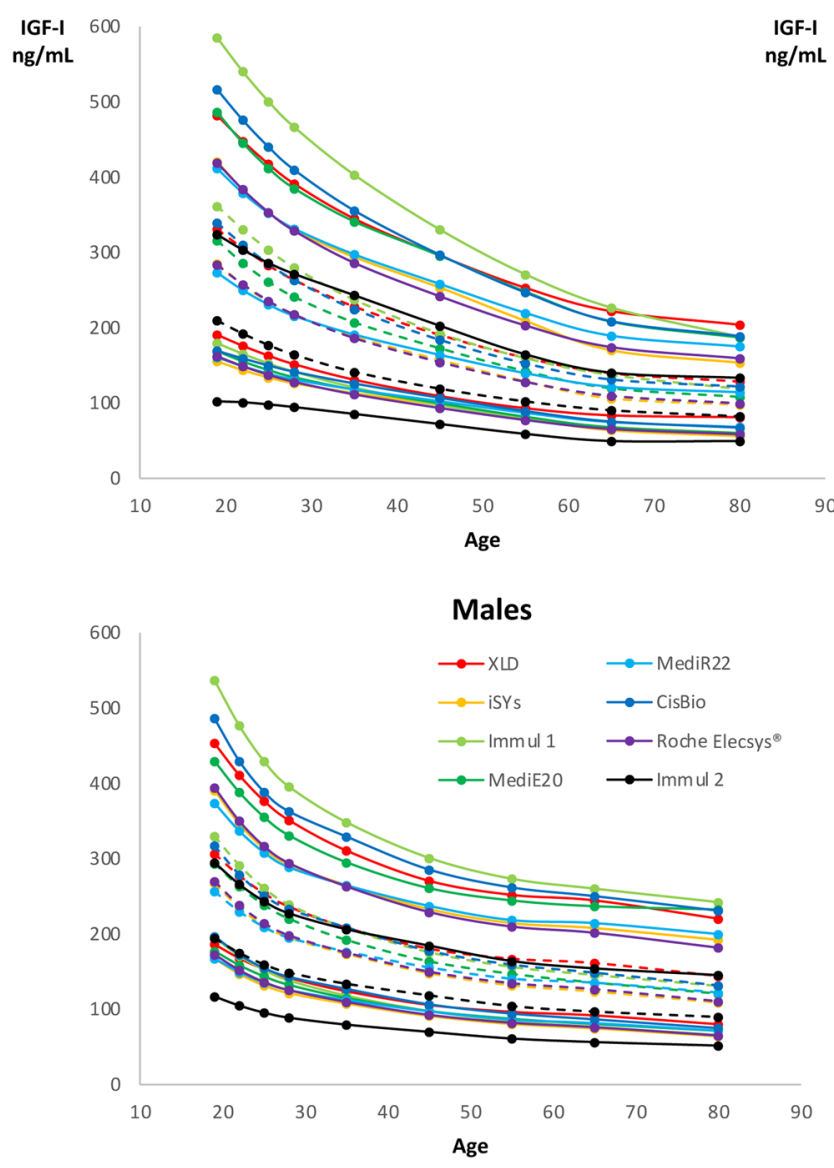

Figure 1

Reference intervals (upper panel, males; lower panel, females) according to the age intervals of the eight immunoassays tested. Lower limits (2.5th percentile) and upper limits (97.5th percentile) of the normal range are drawn as full lines and medians as dotted lines. Each assay has a different color.

of healthy individuals of the VARIETE cohort (3), a sample that reflected all age groups and strictly excluded patients with concomitant medication or underlying disease potentially interfering with IGF-1 measurements. The use of this representative control group also enabled us to compare the concordance among the different assays and to analyze the interassay variability for the same individual patient.

A comparison of the two new assays with the iSYS IGF-1 assay was performed (Fig. 2) since this assay is widely used in clinical practice and was the first one commercially available. Normative data in a very large healthy population of all classes of age that strictly adhered to the latest consensus criteria have been previously published (24). Whereas the concordance with the ROCHE Elecsys ${ }^{\circ}$ assay was good, a distinct discrepancy with the new IMMULITE 2000 could be found. The 2.5 th and 97.5th percentiles with the new IMMULITE $2000 \mathrm{kit}$ calibrated against the recommended standard $(02 / 254)$ were generally lower than those found with the other assays, especially as compared to the previous IMMULITE 2000 (old calibration). Nevertheless, one can underline that calibration against the new standard (WHO NIBSSC $02 / 254$ ) only plays a minor role in reported discordances among IGF-I assays.

Of note, compared to the reference intervals for the iSYS IGF-1 assay reported in the study by Bidlingmaier et al. (24), minimal differences in the 2.5th and 97.5th percentiles, as well as in the intervals, were observed for the same assay in our study, which we have already reported (3). The most likely explanation for these slight variations might be the strict exclusion of underlying comorbidities and factors interfering with IGF-1 in our cohort, including a detailed clinical examination with the assessment of gonadal status and a careful history of potentially confounding medications. In addition, inherent statistical limitations of the LMS method used for the calculation of normative age-specific data were recently suggested to partly contribute to the observed disagreement of assayspecific reference levels (25).

Despite the fact that all assays except IMMULITE 2000 (old calibration) and IGF RIACT were calibrated against the same recommended standard and that most of the assays use automated methods for analysis, distinct variations in the reference intervals could be observed. It is, therefore, likely that other analytical factors, such as interference with high-affinity IGFBPs, might play an important role in explaining the interference in the detection of IGF-1 (26). Differences in the efficacy of removing IGFBP might explain the discordance among the assays, especially in the upper normal range. This might be relevant, although all of the assays use similar techniques to avoid IGFBP interference, including the same non-competitive 'sandwich' format and the addition of IGF-2 (27). We did not test for stability of the VARIETE samples for IGF-I when stored during a long period which could theoretically affect differently matrix effects of immunoassays and thus lead to discrepant results. In fact, this issue has been previously studied showing excellent stability of frozen serum levels of IGF-I when measured by different immunoassays using the same methodology of ours $(28,29)$. In the future, liquid chromatography (LC) tandem mass spectrometry (MS) might offer a promising technique to overcome the impact of binding proteins $(30,31)$. LC-MS has already been reported to offer an independent method for the
This work is licensed under a Creative Commons Attribution-NonCommercial 4.0 International License. ded from Bioscientifica.com at 04/26/2023 08:46:11AM via free access 
iSYS vs ROCHE Elecsys ${ }^{\circledR}$

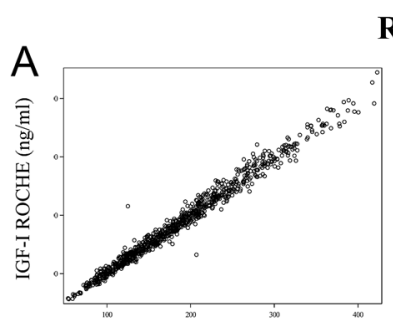

IGF-I iSYS (ng/ml)

Raw data

$\mathrm{B}_{\odot}$

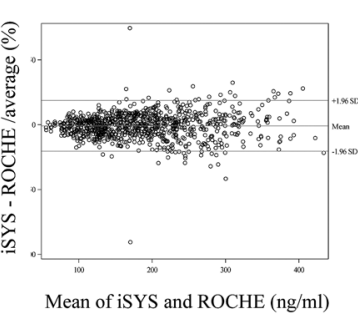

iSYS vs IMMULITE new Raw data

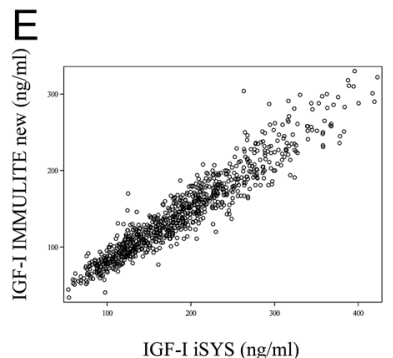

$\mathrm{F}_{\mathrm{o}}$

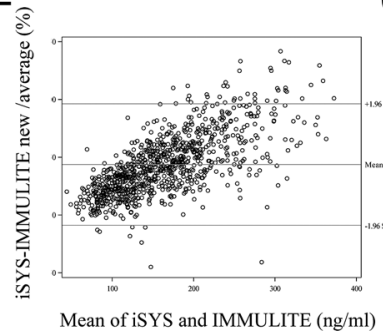

iSYS vs ROCHE Elecsys ${ }^{\circledR}$

SDS

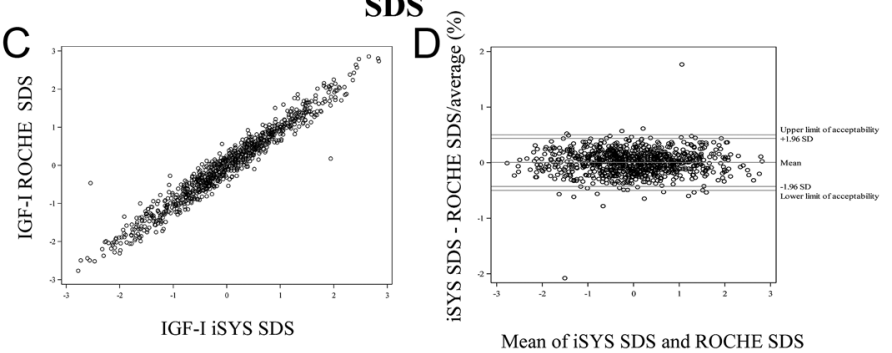

iSYS vs IMMULITE New

SDS
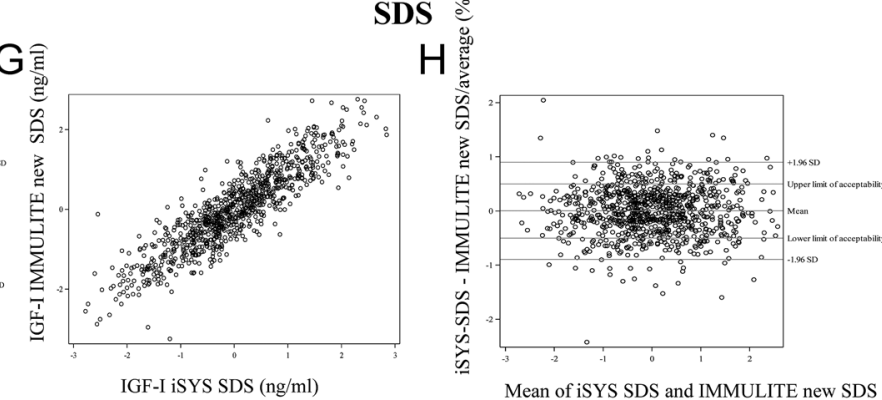

Mean of iSYS SDS and IMMULTE new SDS

Figure 2

Comparisons between iSYS and ROCHE Elecsys ${ }^{\circledR}$ expressed as scatter plots (A) or Bland-Altman plots (B) for raw data, or scatter plots (C) and BlandAltman plots (D) for SDS showing a good overall agreement between both immunoassays, with no significant bias. Comparisons between iSYS and Immulite new calibration expressed as scatter plots (E) or Bland-Altman plots (F) for raw data, or scatter plots (G) and Bland-Altman plots (H) for SDS showing a bad overall agreement between these two immunoassays.

assessment of IGF-1 in patients with acromegaly (32), with acceptable imprecision between different laboratories (33). However, reference values for IGF-1 obtained by LC-MS seem to be similar to those found by the use of immunoassays (34). Additionally, currently, LC-MS is a complex, time-consuming, and expansive method, and immunoassays have their place in routine clinical care.

In conclusion, our study provides reference intervals for two new immunoassays. We also demonstrated a significant variance in the reference values for IGF-1 using eight different commercially available and widely used immunoassays despite all of them being tested on the same large representative healthy population. Our findings highlight the importance of caution in the interpretation of IGF-1 concentrations obtained with different assays, especially in the upper reference range, since the agreement among the assays is only moderately independent of the use of mass units or SD scores. If possible, patients with GH disorders should be monitored by the same IGF-1 assay.

Table 3 Agreement of each IGF-1 assay method against each of the others, with the two new kits IMMULITE (new standard) and ROCHE expressed as weighted Kappa.

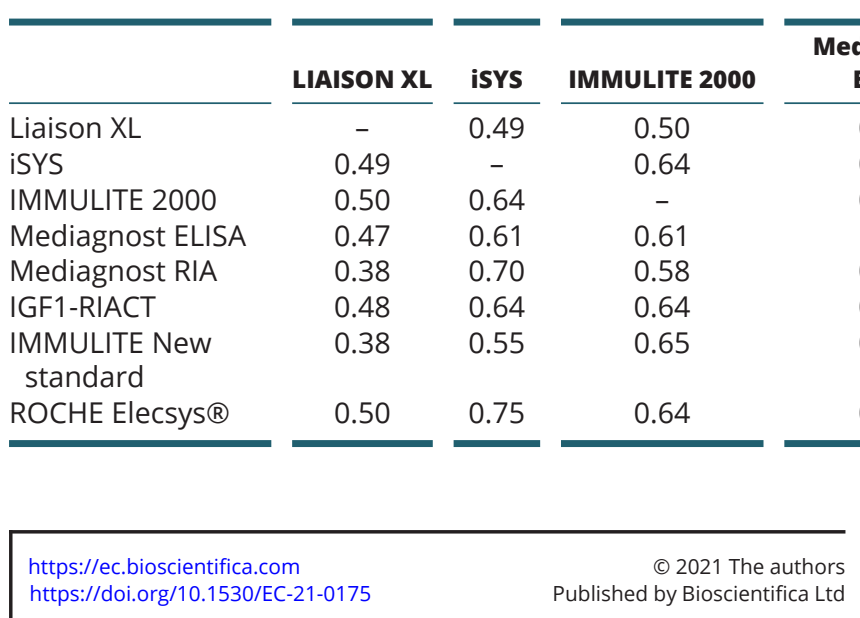

\begin{tabular}{c}
$\begin{array}{c}\text { Mediagnost } \\
\text { ELISA }\end{array}$ \\
\hline 0.47 \\
0.61 \\
0.61 \\
- \\
0.59 \\
0.53 \\
0.55 \\
0.61 \\
\hline
\end{tabular}

\begin{tabular}{c}
\hline Mediagnost RIA \\
\hline 0.38 \\
0.70 \\
0.58 \\
0.59 \\
- \\
0.48 \\
0.49 \\
0.68 \\
\hline
\end{tabular}
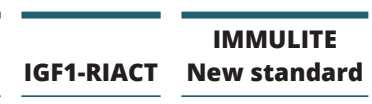

0.48
0.64
0.64
0.53
0.48

0.38

0.55

0.65

0.55

0.49

0.55

0.55

$-$

0.62

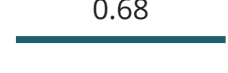

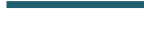

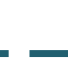

0.56 


\section{Supplementary materials}

This is linked to the online version of the paper at https://doi.org/10.1530/ EC-21-0175.

\section{Declaration of interest}

The authors declare that there is no conflict of interest that could be perceived as prejudicing the impartiality of the research reported.

\section{Funding}

This study was supported by a grant from Programme Hospitalier de Recherche Clinique, French Ministry of Health, no. P081216/IDRCB 2009A00892-55 to P C. P W was supported by a research fellowship of the endocrinology section of the UEMS and the FDIME internal medicine research grant.

\section{Acknowledgements}

The authors thank Roche diagnostics, Siemens, Cisbio International, DiaSorin, IDS, and Mediagnost for the kind donation of IGF-1 kits. The VARIETE Investigators: a complete list of the Valeurs de Référence de I'IGF-I Et Transformation En Z-score (VARIETE) study investigators are given in the Supplementary Appendix.

\section{References}

1 Melmed S, Bronstein MD, Chanson P, Klibanski A, Casanueva FF, Wass JAH, Strasburger CJ, Luger A, Clemmons DR \& Giustina A. A consensus statement on acromegaly therapeutic outcomes. Nature Reviews: Endocrinology 201814 552-561. (https://doi.org/10.1038/ s41574-018-0058-5)

2 Molitch ME, Clemmons DR, Malozowski S, Merriam GR, Vance ML $\&$ Endocrine Society. Evaluation and treatment of adult growth hormone deficiency: an Endocrine Society clinical practice guideline. Journal of Clinical Endocrinology and Metabolism 201196 1587-1609. (https://doi.org/10.1210/jc.2011-0179)

3 Chanson P, Arnoux A, Mavromati M, Brailly-Tabard S, Massart C, Young J, Piketty ML, Souberbielle JC \& VARIETE Investigators. Reference values for IGF-I serum concentrations: comparison of six immunoassays. Journal of Clinical Endocrinology and Metabolism 2016 101 3450-3458. (https://doi.org/10.1210/jc.2016-1257)

4 Granada ML, Ulied A, Casanueva FF, Pico A, Lucas T, Torres E \& Sanmartí A. Serum IGF-I measured by four different immunoassays in patients with adult GH deficiency or acromegaly and in a control population. Clinical Endocrinology 200868 942-950. (https://doi. org/10.1111/j.1365-2265.2007.03120.x)

5 Clemmons DR. Consensus statement on the standardization and evaluation of growth hormone and insulin-like growth factor assays. Clinical Chemistry 201157 555-559. (https://doi.org/10.1373/ clinchem.2010.150631)

6 Mavromati M, Kuhn E, Agostini H, Brailly-Tabard S, Massart C, Piketty ML, Arnoux A, Young J, Souberbielle JC \& Chanson P. Classification of patients with GH disorders may vary according to the IGF-I assay. Journal of Clinical Endocrinology and Metabolism $2017 \mathbf{1 0 2}$ 2844-2852. (https://doi.org/10.1210/jc.2017-00202)

7 Burns C, Rigsby P, Moore M \& Rafferty B. The first international standard for insulin-like growth factor-1 (IGF-1) for immunoassay: preparation and calibration in an international collaborative study. Growth Hormone and IGF Research 200919 457-462. (https://doi. org/10.1016/j.ghir.2009.02.002)

8 Fleiss J, Levin B \& Cho M. Statistical Methods for Rates and Proportions, 3rd ed.New York, NY, USA:Wiley, 2003
9 Cicchetti DV \& Allison T. A new procedure for assessing reliability of scoring EEG sleep recordings. American Journal of EEG Technology 1971 11 101-110. (https://doi.org/10.1080/00029238.1971.11080840)

10 Landis JR \& Koch GG. The measurement of observer agreement for categorical data. Biometrics 197733 159-174. (https://doi. $\operatorname{org} / 10.2307 / 2529310)$

11 Broeren MAC, Krabbe JG, Boesten LS, Hokken-Koelega ACS \& De Rijke YB. Impact of the choice of IGF-I assay and normative dataset on the diagnosis and treatment of growth hormone deficiency in children. Hormone Research in Paediatrics 201890 181-189. (https://doi. org/10.1159/000493133)

12 Alberti C, Chevenne D, Mercat I, Josserand E, Armoogum-Boizeau P, Tichet J \& Léger J. Serum concentrations of insulin-like growth factor (IGF)-1 and IGF binding protein-3 (IGFBP-3), IGF-1/IGFBP-3 ratio, and markers of bone turnover: reference values for French children and adolescents and z-score comparability with other references. Clinical Chemistry 201157 1424-1435. (https://doi.org/10.1373/ clinchem.2011.169466)

13 Juul A. Serum levels of insulin-like growth factor I and its binding proteins in health and disease. Growth Hormone and IGF Research 2003 13 113-170. (https://doi.org/10.1016/s1096-6374(03)00038-8)

14 Lenders NF, McCormack AI \& Ho KKY. Management of endocrine disease: does gender matter in the management of acromegaly? European Journal of Endocrinology 2020182 R67-R82. (https://doi. org/10.1530/EJE-19-1023)

15 Casazza K, Higgins PB, Fernández JR, Goran MI \& Gower BA. Longitudinal analysis of the insulin-like growth factor system in African-American and European American children and adolescents. Journal of Clinical Endocrinology and Metabolism 200893 4917-4923. (https://doi.org/10.1210/jc.2008-0999)

16 Zhu H, Xu Y, Gong F, Shan G, Yang H, Xu K, Zhang D, Cheng X, Zhang Z, Chen S, et al. Reference ranges for serum insulin-like growth factor I (IGF-I) in healthy Chinese adults. PLoS ONE 201712 e0185561. (https://doi.org/10.1371/journal.pone.0185561)

17 Friedrich N, Thuesen B, Jrøgensen T, Juul A, Spielhagen C, Wallaschofksi $\mathrm{H} \&$ Linneberg A. The association between IGF-I and insulin resistance: a general population study in Danish adults. Diabetes Care 201235 768-773. (https://doi.org/10.2337/dc11-1833)

18 Bereket A, Lang CH \& Wilson TA. Alterations in the growth hormoneinsulin-like growth factor axis in insulin dependent diabetes mellitus. Hormone and Metabolic 199931 172-181. (https://doi. org/10.1055/s-2007-978716)

19 Aleidi SM, Shayeb E, Bzour J, Abu-Rish EY, Hudaib M, Alawi SAl \& Bustanji Y. Serum level of insulin-like growth factor-I in type 2 diabetic patients: impact of obesity. Hormone Molecular Biology and Clinical Investigation 201939 20190015. (https://doi.org/10.1515/hmbci-20190015)

20 Dogansen SC, Yalin GY, Tanrikulu S \& Yarman S. Impact of glucose metabolism disorders on IGF-1 levels in patients with acromegaly. Hormone and Metabolic 201850 408-413. (https://doi. org/10.1055/a-0594-2404)

21 Brick DJ, Gerweck AV, Meenaghan E, Lawson EA, Misra M, Fazeli P, Johnson W, Klibanski A \& Miller KK. Determinants of IGF1 and GH across the weight spectrum: from anorexia nervosa to obesity. European Journal of Endocrinology 2010163 185-191. (https://doi. org/10.1530/EJE-10-0365)

22 Adamek A \& Kasprzak A. Insulin-like growth factor (IGF) system in liver diseases. International Journal of Molecular Sciences 2018191308. (https://doi.org/10.3390/ijms19051308)

23 Meinhardt UJ \& Ho KKY. Regulation of growth hormone action by gonadal steroids. Endocrinology and Metabolism Clinics of North America 200736 57-73. (https://doi.org/10.1016/j.ecl.2006.11.009)

24 Bidlingmaier M, Friedrich N, Emeny RT, Spranger J, Wolthers OD, Roswall J, Körner A, Obermayer-Pietsch B, Hübener C, Dahlgren J, et al. Reference intervals for insulin-like growth factor-1 (IGF-I) from birth to senescence: results from a multicenter study using a new

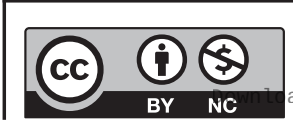

This work is licensed under a Creative Commons Attribution-NonCommercial 4.0 International License. ated from Bioscientifica com at 04/26/2023 08:46:11AM 
automated chemiluminescence IGF-I immunoassay conforming to recent international recommendations. Journal of Clinical Endocrinology and Metabolism 201499 1712-1721. (https://doi. org/10.1210/jc.2013-3059)

25 Varewijck AJ, Lely AJ van der, Neggers SJCMM, Hofland LJ \& Janssen JAMJL. Disagreement in normative IGF-I levels may lead to different clinical interpretations and GH dose adjustments in GH deficiency. Clinical Endocrinology 201888 409-414. (https://doi. org/10.1111/cen.13491)

26 Frystyk J, Freda P \& Clemmons DR. The current status of IGF-I assays - a 2009 update. Growth Hormone and IGF Research 201020 8-18. (https://doi.org/10.1016/j.ghir.2009.09.004)

27 Blum WF \& Breier BH. Radioimmunoassays for IGFs and IGFBPs. Growth Regulation 19944 (Supplement 1) 11-19.

28 Ito Y, Nakachi K, Imai K, Hashimoto S, Watanabe Y, Inaba Y, Tamakoshi A, Yoshimura T \& JACC Study Group. Stability of frozen serum levels of insulin-like growth factor-I, insulin-like growth factor-II, insulin-like growth factor binding protein-3, transforming growth factor beta, soluble Fas, and superoxide dismutase activity for the JACC study. Journal of Epidemiology 200515 (Supplement 1) S67-S73. (https://doi.org/10.2188/jea.15.s67)

29 Elmlinger MW, Zwirner M \& Kühnel W. Stability of insulin-like growth factor (IGF)-I and IGF binding protein (IGFBP)-3 measured by the immulite automated chemiluminescence assay system in different blood specimens. Clinical Laboratory 200551 145-152.
30 Hoofnagle AN, Whiteaker JR, Carr SA, Kuhn E, Liu T, Massoni SA, Thomas SN, Townsend RR, Zimmerman LJ, Boja E, et al. Recommendations for the generation, quantification, storage, and handling of peptides used for mass spectrometry-based assays. Clinical Chemistry 201662 48-69. (https://doi.org/10.1373/ clinchem.2015.250563)

31 Censi S, Barollo S, Grespan E, Watutantrige-Fernando S, Manso J, Iacobone M, Casal Ide E, Galuppini F, Fassina A, Bertazza L, et al. Prognostic significance of TERT promoter and BRAF mutations in TIR-4 and TIR-5 thyroid cytology. European Journal of Endocrinology 2019 181 1-11. (https://doi.org/10.1530/EJE-19-0073)

32 Kay R, Halsall DJ, Annamalai AK, Kandasamy N, Taylor K, Fenwick S, Webb A, Wark G, Pleasance S \& Gurnell M. A novel mass spectrometrybased method for determining insulin-like growth factor 1: assessment in a cohort of subjects with newly diagnosed acromegaly. Clinical Endocrinology 201378 424-430. (https://doi.org/10.1111/cen.12085)

33 Cox HD, Lopes F, Woldemariam GA, Becker JO, Parkin MC, Thomas A, Butch AW, Cowan DA, Thevis M, Bowers LD, et al. Interlaboratory agreement of insulin-like growth factor 1 concentrations measured by mass spectrometry. Clinical Chemistry 201460 541-548. (https://doi. org/10.1373/clinchem.2013.208538)

34 Bystrom C, Sheng S, Zhang K, Caulfield M, Clarke NJ \& Reitz R. Clinical utility of insulin-like growth factor 1 and 2; determination by high resolution mass spectrometry. PLoS ONE 20127 e43457. (https:// doi.org/10.1371/journal.pone.0043457)

Received in final form 24 July 2021

Accepted 3 August 2021

Accepted Manuscript published online 3 August 2021 https://ec.bioscientifica.com

https://doi.org/10.1530/EC-21-0175 (c) 2021 The authors Published by Bioscientifica Ltd
This work is licensed under a Creative Commons Attribution-NonCommercial 4.0 International License. ded from Bioscientifica.com at $04 / 26 / 2023$ 08:46:11AM 